\title{
Decline in snowfall in response to temperature in Satluj basin, western Himalaya
}

\author{
Riyaz Ahmad Mir ${ }^{1,2, *}$, Sanjay K Jain ${ }^{3}$, Arun K Saraf ${ }^{1}$ and Ajanta Goswami ${ }^{4}$ \\ ${ }^{1}$ Department of Earth Sciences, Indian Institute of Technology, Roorkee 247 667, India. \\ ${ }^{2}$ Geological Survey of India, State Unit: JEKK, Srinagar, 190 008, India. \\ ${ }^{3}$ National Institute of Hydrology, Roorkee 247667 , India. \\ ${ }^{4}$ Indian Institute of Remote Sensing, Dehradun 248 001, India. \\ *Corresponding author.e-mail: riyazgsi@gmail.com; riyaz.mir@gsi.gov.in
}

Snow is an essential resource present in the Himalaya. Therefore, monitoring of the snowfall changes over a time period is important for hydrological and climatological purposes. In this study, variability of snowfall from 1976-2008 were analysed and compared with variability in temperature $\left(T_{\max }\right.$ and $\left.T_{\min }\right)$ from 1984-2008 using simple linear regression analysis and Mann-Kendall test in the Satluj Basin. The annual, seasonal, and monthly analyses of average values of snowfall and temperature $\left(T_{\max }\right.$ and $\left.T_{\min }\right)$ have been carried out. The study also consists an analysis of average values of annual snowfall and temperature over six elevation zones $(<1500$ to $>4000 \mathrm{~m}$ amsl). During the study, it was observed that the snowfall exhibited declining trends in the basin. The snowfall trends are more sensitive to the climate change below an elevation of $4000 \mathrm{~m}$ amsl. Over the elevation zones of 3000-3500 and 4000-4500 m amsl, positive trends of mean annual values of snowfall were observed that may be due to higher precipitation as snowfall at these higher elevations. Although, both negative and positive snowfall trends were statistically insignificant, however, if this decreasing trend in snowfall continues, it may result in significant however, changes in future. Furthermore, the $T_{\min }$ is also increasing with statistically significant positive trend at 95\% confidence level for November, winter season, annually as well as for the elevation zones of 2500-3000, 3000-3500, and 3500-4000 m amsl. There are dominantly increasing trends in $T_{\max }$ with negative trends for February, June-September, monsoon season, and for elevation zone $<1500 \mathrm{~m}$ amls. It is important to state that in the present basin, during the months of winter season, most of the precipitation is produced as snowfall by the westerly weather disturbances. Thus, the declining nature in snowfall is concurrent with the positive trends in temperature particularly $T_{\min }$, therefore, reflecting that the positive trends in $T_{\min }$ may be the dominant factor besides $T_{\max }$ in controlling the snowfall trends. The snowfall data were also compared with SCA and this showed a highly positive correlation of $0.95 \%$ which validates the utilisation of time series of snowfall for the trend analysis.

\section{Introduction}

The Himalayan Mountains account for almost $70 \%$ of non-polar glaciers. In winter season, most of the high-altitude areas in this region experience snowfall to form permanent snow fields (Kulkarni et al. 2002). Snow melt affects water management through annual runoff, recharge, and water supplies. The snow melt is the dominant source of many rivers, which are considered to be the lifeline of millions of people, originating from the Himalayas in the summer season. The fresh water

Keywords. Snowfall; SCA; temperature; Himalaya; climate change. 
from melting of snow is important for local drinking water supplies (Woodwell 2004; Meissner and Reller 2005) flood control, and agricultural purposes (Keller et al. 2000; Pimentel et al. 2004; Deems et al. 2006; Armstrong and Brun 2008). Therefore, monitoring of snowfall in these regions is essential for the development of ecosystems, human activities like agriculture, hydropower generation, etc. However, in the 20th century, rapid industrialization caused a huge increase in global temperature with large emissions of $\mathrm{CO}_{2}$, trace gases and aerosols (IPCC 2001). Due to the increasing level of global warming, regions will increasingly receive precipitation in the form of rain rather than snowfall and the snowline will rise by about $150 \mathrm{~m}$ for every $1^{\circ} \mathrm{C}$ increase in temperature (Schadler 2004). The snow has high reflectivity, emissivity and low thermal conductivity. The snow is a key variable in the global climatic system as it affects the global heat budget chiefly due to its influence of increasing surface albedo and outgoing long wave radiation on the surface temperature (Barnett et al. 1989; Groisman et al. 1994).

Snowfall responds, directly or indirectly, to a range of meteorological parameters (e.g., air temperature, wind, precipitable water, atmospheric circulation patterns, frontal activity, lapse rate, and stability of the air mass) that influence snow accumulation and distribution, during the winter accumulation period. Snowfall and hence, snow cover are cited as useful indicators of climate fluctuations (Barry 1985; Chang et al. 1990; Goodison and Walker 1993; Derksen et al. 1998; Serreze et al. 2000). There are many studies on long-term snow changes on regional as well as global scales (Brown et al. 2000; Beniston et al. 2003; Kazuyuki 2003; Laternser and Schneebeli 2003). Frei et al. (1999) have reported snow cover variation and their relationships to temperature in the northern hemisphere. Dickson (1984) and Clark et al. (1999) have studied the climatic effect of Eurasian snow cover on Indian monsoon rainfall, the interaction of snow depth in the former Union of Soviet Socialist Republics (USSR) with Indian monsoon rainfall and found a significant relationship (Kripalani and Kulkarni 1999). Bednorz (2004) studied snow cover in Eastern Europe in relation to temperature, precipitation, and circulation. In western Canada, significant reductions in snow depth have been reported (Brown and Goodison 1996; Brown 1998). Ke et al. (2009) studied snowfall trends and variability in Qinghai, China.

There is a significant impact of recent climate change on the patterns of precipitation on global as well as regional scale. Therefore, understanding the uncertainties associated with precipitation patterns will provide the knowledge base for better management of agriculture, irrigation, hydropower generation and other water-related activities. In the present paper, the annual, seasonal, monthly, and elevation-wise trend analysis of snowfall in Satluj basin have been evaluated in relation to trends in temperature $\left(T_{\max }\right.$ and $\left.T_{\min }\right)$. Further, comparative analysis of snowfall and (MODIS) derived snow cover area (SCA) from 2000-2009 has also been taken up for the validation of the ground based snowfall data.

\section{The study area}

The Satluj River originates from the Tibetan Plateau at an elevation $>4500 \mathrm{~m}$ amsl in the southern slopes of Mount Kailash and flows generally west and southwest entering India in Himachal Pradesh. In the Tibetan Plateau, the entire basin is characterized by a cold desert winter climate which, therefore, leads to a very low flow in the river until it joins its major tributary, Spiti, near Namgia in Himachal Pradesh. The Spiti catchment in the winter months experiences extensive snowfall due to westerly weather disturbances and therefore contributes to the Satluj flow in spring months (Singh and Kumar 1997). Asia's second highest gravity dam is constructed at the outlet of the river at Bhakra in Himachal Pradesh. The Satluj River is one of the important tributaries of the Indus river system as well. The river's total length is $1448 \mathrm{~km}$ and total drainage area up to Bhakra reservoir is about $56,500 \mathrm{~km}^{2}$. However, for the present study, the Indian part of the Satluj River basin $\left(30^{\circ} 22^{\prime}-\right.$ $32^{\circ} 42^{\prime} \mathrm{N}$ and $\left.75^{\circ} 57^{\prime}-78^{\circ} 51^{\prime} \mathrm{E}\right)$ up to Bhakra reservoir was selected (figure 1). The Indian part of the Satluj basin covers an area of about $22,305 \mathrm{~km}$. The elevation ranges from about 500 to $7000 \mathrm{~m}$, although only a small area exists above $6000 \mathrm{~m}$. Due to the large differences in the elevation range and seasonal temperatures, the snow line goes down to an elevation of about $2000 \mathrm{~m}$ during winter and reaches up to $5000 \mathrm{~m}$ elevation at the end of the summer. However, the permanent snow line is observed to be around $5400 \mathrm{~m}$ in this part of the Himalayan region (BBMB 1988). About $65 \%$ of the Satluj basin area is covered with snow during winter and about $12 \%$ of the basin $\left(2700 \mathrm{~km}^{2}\right)$ is covered with permanent snowfields and glaciers (Singh and Bengtsson 2004).

Furthermore, the basin covers outer, middle, and greater Himalayan ranges, but its major part lies in the greater Himalayas. The basin experiences a diverse climate due to the wide range of altitudes and precipitation patterns. Around the lower part of the basin, the tropical and warm temperate climate prevails, whereas the middle part has a cold temperate climate. The climate is very cold in the 


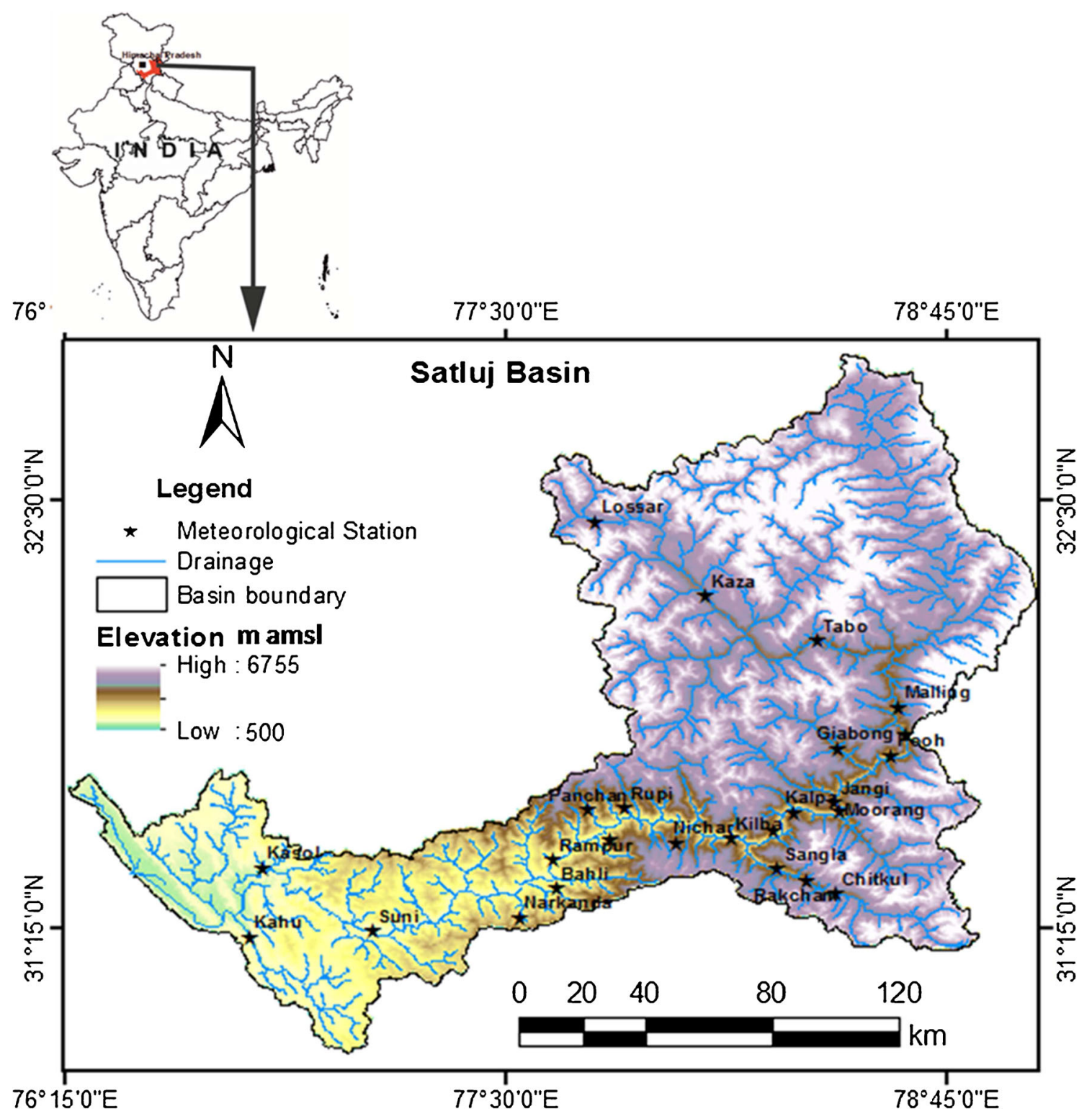

Figure 1. Location of the study area and meteorological stations in the Satluj basin.

upper part whereas in the uppermost part, which is a perpetually frozen area (permafrost), the climate is similar to the Polar regions. In the upper part of the basin, most of the precipitation is produced by the westerly weather disturbances, embedded in large scale westerlies (Dimri and Mohanty 2007), which originate in the Mediterranean Sea and bring sudden snow during winter months. This precipitation pattern is non-monsoonal in character (Hasnain 2008). The lower part of the basin receives only rain, whereas the middle part gets both rain and snow. The average annual rainfall in the outer, middle, and greater Himalayan ranges of this basin is about 1300, 700, and $200 \mathrm{~mm}$, respectively (Singh and Kumar 1997), indicating that the rainfall is concentrated in the lower part of the basin. Over Western Himalaya, the winter precipitation is important as it is the major source of water for north Indian rivers (Thayyen and Gergan 2010). However, the changing precipitation and temperature patterns (Dimri and Dash 2012) appear to impact this source and affect the hydrological regimes (Yang et al. 2002; Thayyen and Gergan 2010) of these river systems. The flow during spring season in the Satluj River comes mainly from the runoff generated by snowmelt from the upper elevations in the greater Himalayas (Jain et al. 1998). On average, the contribution to annual runoff from snow and glaciers is estimated at about $60 \%$ (Singh and Jain 2002). Snowmelt contribution starts from March and lasts until June/July depending upon the snowpack water equivalent accumulated in winter and prevailing temperatures in summer season. In April-June (pre-monsoon 
season), major part of the stream flow is produced from seasonal snow. The glacier melt runoff in the months of July-August-September occurs after the contribution of seasonal snowmelt, when glaciers become snow free (Singh and Quick 1993). However, as the summer season precedes the production of snowmelt increases continuously and exceeds the rainfall component. The lower part of the Satluj basin experiences a considerable amount of monsoon rainfall. Temperature has a peak in June when the snowmelt contributed flow usually reaches its peak. Peak values of total discharge in July and August are essentially due to combining snowmelt with monsoon rainfall in the lower elevations. Minimum flow is observed in winter when the base flow contribution sustains the river flow (Jain et al. 2010).

\section{Data used}

\subsection{Meteorological data}

The snowfall and temperature $\left(T_{\max }\right.$ and $\left.T_{\min }\right)$ data were procured from Bhakra Beas Management Board (BBMB), Nangal, India. The details of the meteorological stations are given in table 1 . A complete and continuous time series of snowfall over a period of 33 years (1976-2008) was selected for the study. About 21 snow gauges have been established in the Indian part of Satluj basin for the estimation of daily snowfall (Anonymous 1988). The snowfall represents the solid precipitation in the present basin, which is measured by melting the daily snow accumulations. The snowfall measurements are made by snow pit method and using instruments like snow pillows, etc., at a number of points in the basin. Therefore, this data was used for trend analysis after applying certain corrections (Sevruk 1985). The daily surface air temperature ( $T_{\max }$ and $\left.T_{\min }\right)$ data was available for seven stations from 1984 to 2008. The stations collecting the data are spread throughout the basin at different altitudes. The elevation information for various meteorological stations indicates that the stations are located around much higher elevation.

\subsection{Snow cover area}

SCA maps were generated using the MODIS snow data products. The snow product used in this study is MODIS/Terra Snow Cover 8-Day L3 Global 500 m Grid (MOD10A2), Version 5 (Hall et al. 2007), which is available from 24 February, 2000 to 2009. The snow cover products are produced from MODIS data and distributed by the Distributed Active Archive Center (DAAC) from the National Snow and Ice Data Center (NSIDC).
MOD10A2 comes in a spatial resolution of $500 \times$ $500 \mathrm{~m}^{2}$ in every 8 -day period that begins on the first day of each year and extends to first few days of the next year. This product represents the maximum snow extent in the given 8-day period. Monthly snow cover areas were derived taking the average of the spanned 8-day periods in each month for different elevation zones covering the study area.

\subsection{Digital elevation model}

A digital elevation model (DEM) was required to determine the elevation of location of the meteorological stations as well as the various elevation zones. Therefore, a DEM generated by using the Advanced Space-borne Thermal Emission and Reflection Radiometer (ASTER) sensor, which is an imaging instrument onboard the Terra satellite launched in December 1999 as a part of NASA's Earth Observing System (EOS) was used in this study. The resolution of ASTER ranges from 15 to $90 \mathrm{~m}$ depending on the wavelength and records the information in three bands - the visible/nearinfrared (VNIR), the shortwave infrared (SWIR), and the thermal infrared (TIR) - oriented on the nadir and looking backward. Because of its off nadir sensor pointing capability, ASTER can collect the stereo pairs necessary to generate highresolution DEMs (using bands $3 \mathrm{~N}$ and $3 \mathrm{~B}$ ). The ASTER has produced $30 \mathrm{~m}$ resolution elevation data. There is a fairly complete coverage of the Earth at this high resolution and the data are freely available.

\section{Methodology}

Trend analysis was carried out for the mean values of annual, seasonal, and monthly snowfall and temperature $\left(T_{\max }\right.$ and $\left.T_{\min }\right)$ data. For seasonal analysis, each year was divided into four seasons, i.e., December-March (winter season), April-June (pre-monsoon season), July-September (monsoon season) and October-November (post-monsoon season). Since, the meteorological stations are distributed at different elevations in the basin, therefore, to understand the trends elevation-wise, we divided the basin into several elevation zones using DEM (ASTER) as shown in figure 2. The elevation of the location of each meteorological station was also calculated from DEM. The elevation zones are represented by either one, two, or more stations as given in table 2. The data from each station falling within a particular elevation zone were added up and an average value was calculated for further analysis. 
Table 1. Geographic characteristics and data information of the meteorological stations analysed in the study area (Satluj basin).

\begin{tabular}{rlccc}
\hline No. & Station & $\begin{array}{c}\text { Elevation } \\
(\mathrm{m} \text { amsl })\end{array}$ & Longitude & Latitude \\
\hline 1 & Lossar & 4065 & 77.76 & 32.44 \\
2 & Kaza & 3656 & 78.07 & 32.22 \\
3 & Tabo & 3288 & 78.39 & 32.09 \\
4 & Malling & 3006 & 78.62 & 31.90 \\
5 & Namgia & 2675 & 78.64 & 31.82 \\
6 & Pooh & 2516 & 78.60 & 31.76 \\
7 & Giabong & 2920 & 78.44 & 31.78 \\
8 & Jangi & 2310 & 78.43 & 31.62 \\
9 & Moorang & 2761 & 78.45 & 31.60 \\
10 & Kalpa & 2827 & 78.32 & 31.59 \\
11 & Purbani & 2590 & 78.26 & 31.54 \\
12 & Kilba & 2002 & 78.14 & 31.43 \\
13 & Sangla & 2675 & 78.27 & 31.39 \\
14 & Rakcham & 3212 & 78.36 & 31.35 \\
15 & Chitkul & 3426 & 78.44 & 31.50 \\
16 & Nichar & 3600 & 77.99 & 31.60 \\
17 & Rupi & 2331 & 77.84 & 31.51 \\
18 & Sarhan & 2265 & 77.80 & 31.60 \\
19 & Panchan & 2106 & 77.74 & 31.37 \\
20 & Bahli & 2049 & 77.65 & 31.28 \\
21 & Narkanda & 1752 & & \\
\hline
\end{tabular}

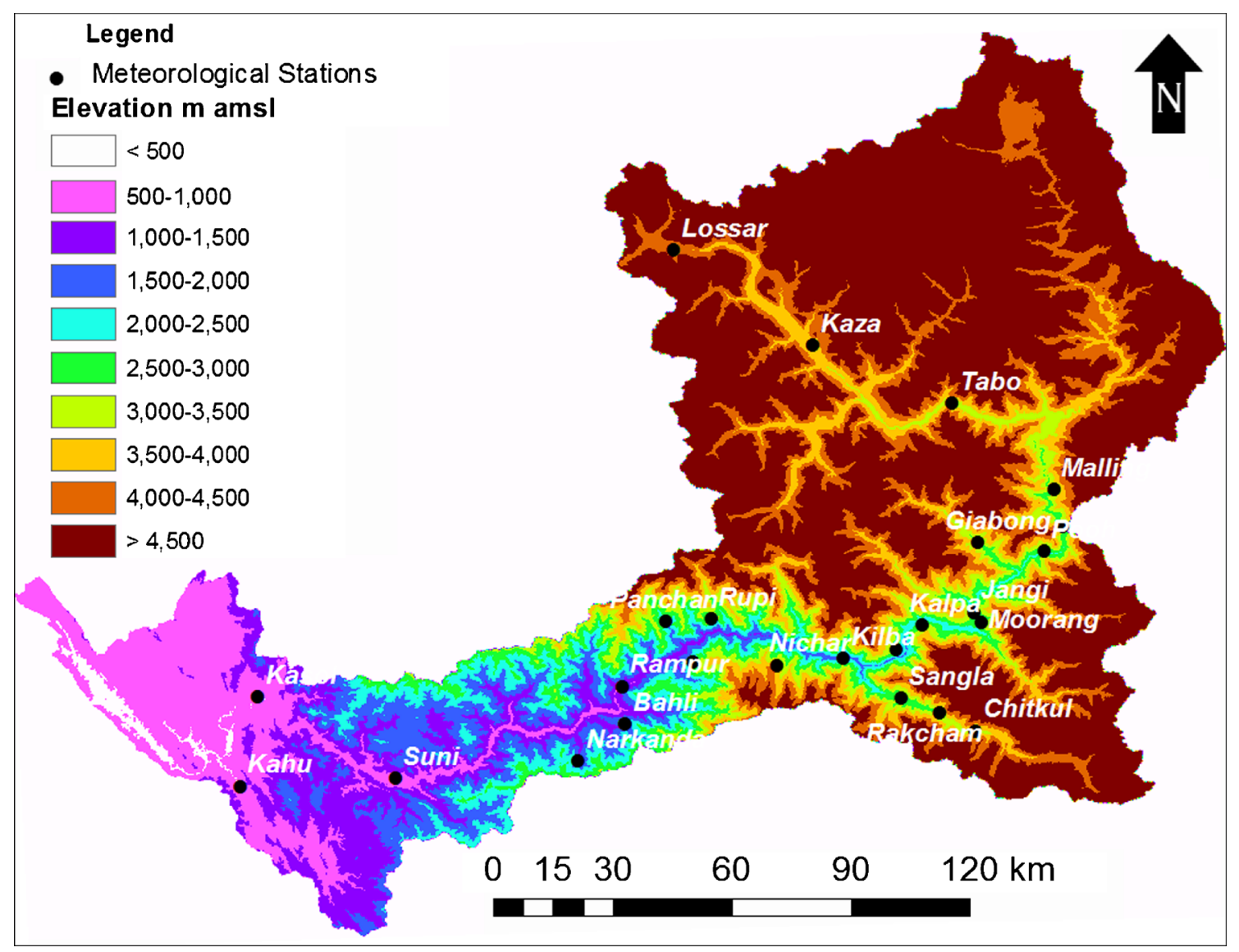

Figure 2. Classification of Satluj basin into 10 elevation zones based on ASTER GDEM and the location of respective meteorological stations in each elevation zone is also presented. 
Table 2. Number of meteorological stations falling in each elevation zone.

\begin{tabular}{lll}
\hline & \multicolumn{2}{c}{ Meteorological stations } \\
\cline { 2 - 3 } Elevation zones $(\mathrm{m}$ amsl) & \multicolumn{1}{c}{ Snowfall } & Temperature $\left(T_{\max }\right.$ and $\left.T_{\min }\right)$ \\
\hline$<1500$ & - & Kasol, Suni, Rampur \\
$1500-2000$ & Narkanda & - \\
$2000-2500$ & Jangi, Bahli, Rupa, Pancha, Sarhan & Namgia, Kalpa \\
$2500-3000$ & Kalpa, Namgia, Kilba, Moorang, Pooh, Purbani, & Rakcham \\
$3000-3500$ & Sangla, Gaibang & Kaza \\
$3500-4000$ & Chitkul, Malling, Rakcham, Tabo & - \\
\hline 4000 & Kaza, Nichar & \\
\hline
\end{tabular}

The analysis was carried out using the linear regression analysis and Mann-Kendall Test (Mann 1945; Kendall 1975). Linear regression analysis is the most useful parametric model to detect the trend 'Simple Linear Regression' model. The linear regression method is based on the assumptions of normality of residuals, constant variance, and true linearity of relationship (Helsel and Hirsch 1992). The main statistical parameter of regression analysis is the slope indicating mean temporal change of the studied variables (like snowfall, temperature in the present study). Positive values of the slope show increasing trends, while negative values indicate decreasing trends. The Mann-Kendall test is a non-parametric test, which is not based on the normal distribution of data. It was originally used by Mann (1945) and Kendall (1975) subsequently derived the test statistic distribution. This test investigates on the presence of a tendency of long period in hydro-meteorological data without making an assumption about its distributional properties. This test is low sensitive to the abrupt breaks due to inhomogeneous time series (Jaagus 2006). This test has been widely used for the detection of trends in hydro-meteorological time series data (Yue and Hashino 2003; Aziz and Burn 2006; Cannarozzo et al. 2006; Mir et al. 2013). In this method, Zs (Z statistics), is used as a test to evaluate the significance of trend. Positive values of Zs point out increasing trends while negative $\mathrm{Zs}$ values demonstrate decreasing trends. In the present paper, significance of trend was measured at $95 \%$ with $\mathrm{Zs}_{\mathrm{s}}=1.96$ confidence level. The magnitude of slope (change per unit time) was estimated using a simple non-parametric procedure developed by Sen (1968).

Furthermore, the Aqua/Terra-MODIS satellite data products available for 9 years (2000-2009) were processed using standard image processing techniques (Lillesand et al. 2004). The images were geometrically corrected for any distortion using image-to-image georectification algorithm (Jensen 1996; Jain et al. 2008). Normalized Difference Snow Index (NDSI) is used for the identification of snow and ice and for separating snow/ice and clouds (Hall et al. 1995; Salomonson and Appel 2006). The NDSI is the difference of reflectance in a visible band and the short-wave infrared band divided by the sum of the two reflectances. The MODIS snow cover algorithm is based on the high reflectance of snow in the visible band (band 4, 0.545-0.565 $\mu \mathrm{m}$ ) and low reflectance in the short wave infrared band (band 6, 1.628-1.652 $\mu \mathrm{m}$ ) and is calculated using the equation:

$$
\text { NDSI }=\frac{\text { Visible Band }- \text { SWIR Band }}{\text { Visible Band }+ \text { SWIR Band }}
$$

On the NDSI images, the reflectance of snow is higher in the visible band than other terrain features. However, the reflectance of clouds remains high in MODIS band $6(1628-1652 \mathrm{~nm})$. Thus, the NDSI provides reliable tools to distinguish between some clouds and snow. A threshold value of 0.40 was used on the NDSI images to classify a pixel as snow covered. The same threshold value has been used by various researchers wherein the pixels with an NDSI value greater than or equal to 0.40 are considered as snow (Dozier 1989; Hall et al. 1995; 2002). The data products were produced in sinusoidal projection and WGS84 datum, which were re-projected to geographic lat./long. The source coordinates were converted to rectified coordinates using the second-order polynomial equation followed by the re-sampling using Nearest Neighbour method. Since, the water bodies such as lakes have similar NDSI values as that of snow, an additional requirement was introduced; the pixel reflectance has to be larger than $11 \%$ in MODIS band 2 (841$876 \mathrm{~nm})$ in order to be mapped as snow. Thus, the images were further classified into snow and non-snow categories.

\section{Comparison of ground-based snowfall data with satellite derived SCA}

Snowfall and low temperature are full circumstances to convene the formation of snow cover. 
Therefore, it is essential to understand the linkage between the variations in temperature and snowfall to find a sign of variations in snow cover/snow season in response to climate change. The most immediate and important effect of climate change on alpine environments worldwide is its impact on snow cover. Globally, average snow cover has decreased by $10 \%$ since the late 1960 s (IPCC 2007). In order to quantify and understand the nature of correlation between the snowfall and SCA data from 2000 to 2009, a comparison has been made elevation-wise. The comparison also validated the ground-based snowfall dataset for trend analysis. The period of the snowfall and snow cover season for the study are same and therefore, there is a general consistency in the snowfall and SCA data.

Figure 3(a) presents distribution of the mean monthly SCA cycles from 2000 to 2009 in the present basin, elevation-wise. The figure illustrates that the snow accumulation starts from October and reaches its peak in January and February. The SCA then starts going down up to May. In general, the maximum SCA exists in March by when most of the snowfall has occurred (Singh and Jain 2003). However, the SCA accumulation behaves differently depending upon the elevation. In the lower elevation zones, the snow accumulation occurs from December to February. From the elevation zone of $2000 \mathrm{~m}$ up to the elevation more than $4000 \mathrm{~m}$, the snow accumulation starts in the month of October. The SCA reaches $100 \%$ in winter season. The SCA decreases substantially in the summer season and is represented by glacier and snow cover at the higher elevation zones. Similar pattern exists for the snowfall as shown in figure 3(b). Snow pack accumulates from October and reaches the peak in January and February. Snow pack starts to shrink slightly after the peak snowfall, i.e., from February onwards. The snow pack starts melting and reaches the minimum snow pack in summer months. It reaches $0 \mathrm{~mm}$ from June to September and there, most of the area in the basin remains snow-free for these months. However, a small percentage $(12 \%)$ of snow is represented by glaciers and snow cover at the higher elevation zones (Singh and Bengtsson 2004).

Comparisons of mean monthly basin SCA with snowfall data showed a significant correlation between seasonal cycles (figure 3a, b); besides some noticeable differences in few months at few elevation zones such as 1500-2000 m amsl. The SCA reaches $100 \%$ in early winter and maintains this peak level throughout the winter season in the studied basin, while the snowfall continues to increase until mid winter and then starts declining slightly before the onset of the spring melt season. During the spring season, the
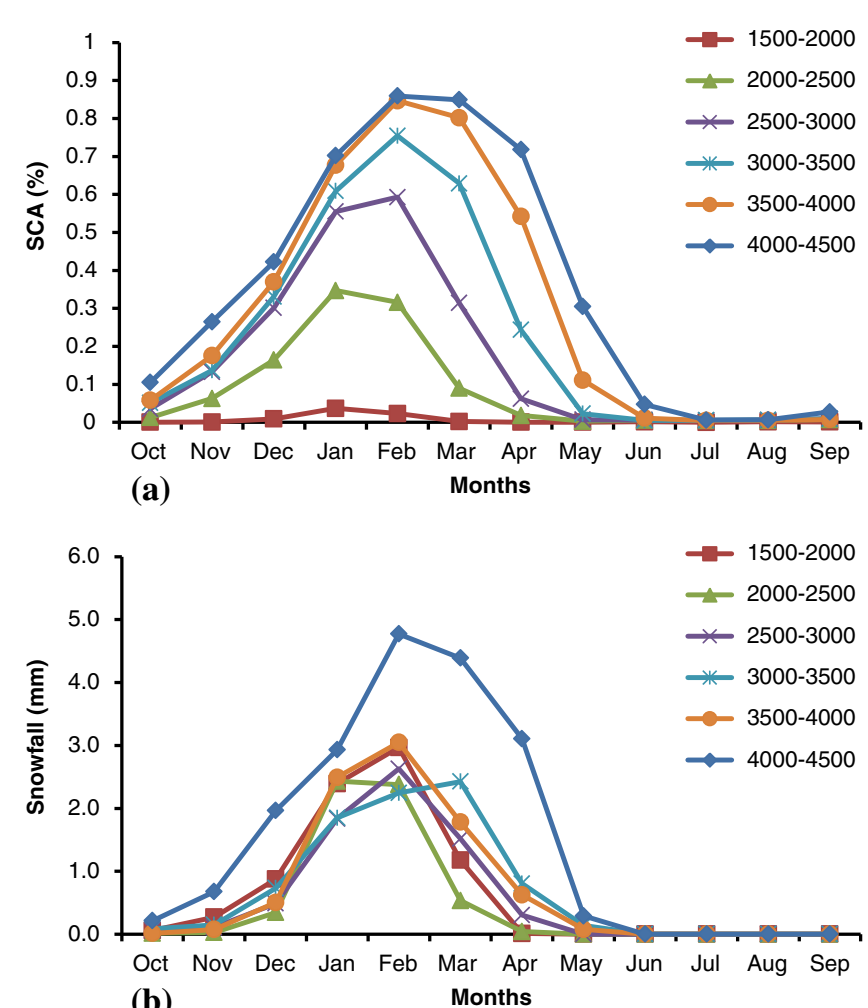

Figure 3. Monthly distribution of (a) mean values of SCA derived from MODIS images and (b) ground-based snowfall from 2000 to 2009 for six elevation zones in the Satluj basin.

snowfall starts to decline due to the increase in spring temperature and melt whereas the SCA maintains at $100 \%$. However, as the melting progresses, further decrease of the snowfall leads to the SCA reduction in the late spring. Both SCA and snowfall reach zero levels during the late spring to early summer. A linear regression approach to define the relationship between snowfall and SCA data has been applied as shown in figure 4(a). The correlation between the mean values of monthly snowfall and SCA showed a highly significant correlation with $R^{2}=0.95$. In order to have a better insight into the relationship, elevation-wise correlation was also carried out as shown in figure 4(b). The correlation coefficient of snowfall and SCA for different elevation zones, i.e., $\left(R^{2}\right)$ varied from 0.78 in an elevation zone of 1500$2000 \mathrm{~m}$ amsl to 0.96 in an elevation zone of $3000-$ $3500 \mathrm{~m}$ amsl. In general, the regression analyses of the monthly basin snowfall versus SCA indicated positive relationships. The better correlation in all the elevation zones was found to be significant, reflecting high accuracy of the snowfall data based on ground stations and therefore, this dataset can be utilised for the trend analysis with confidence. The general compatibility between SCA and snowfall seasonal cycles appreciates the applications of present snowfall data for future hydroclimatic investigations. 

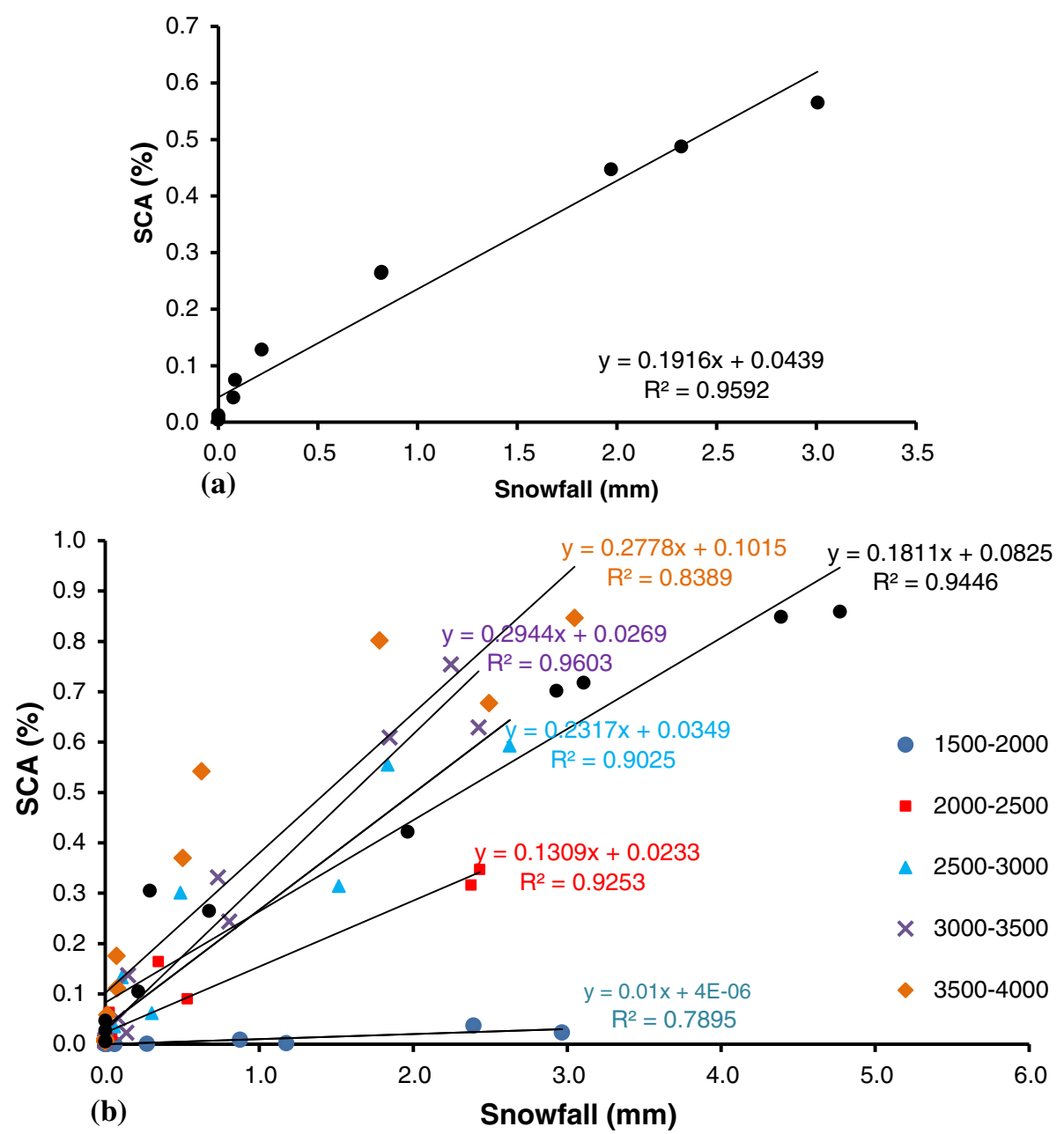

Figure 4. Correlation between the SCA derived from MODIS images and ground-based snowfall from 2000 to 2009 in the Satluj basin. (a) Mean values of SCA and snowfall and (b) elevation-wise mean values of SCA and snowfall.

\section{Results}

\subsection{General characteristics of snowfall}

The snowfall in the study area from January to March was higher, whereas during April to May lower values were observed, which may be attributed to the occurrence of lower snowfall during these months. The snowfall values exhibited zero values from July to September because the precipitation during these months takes place mostly in the form of rainfall. Thus, the monthly variation of snowfall showed higher values during the cold season (winter) and little or no values during the summer months. From 1976-2008, a wide variation in snowfall was observed, from a minimum value of $104 \mathrm{~mm}$ (1999) to a maximum of $451 \mathrm{~mm}$ (1984) with an average value of $251 \mathrm{~mm}$. Month-wise, February showed higher values (51 $\mathrm{mm}$ ) accounting for $29 \%$ followed by January and March with 41 and $43 \mathrm{~mm}$ contributing $24 \%$ and $24 \%$, respectively to the total annual snowfall. October showed the lowest values
(1.4 mm) accounting for 1\%. From June to September, negligible values of snowfall were observed. In addition to this, higher values were observed during winter season $(111 \mathrm{~mm})$ and pre-monsoon season $(57 \mathrm{~mm})$ followed by lower values in post-monsoon season $(7 \mathrm{~mm})$. During the monsoon season, there was no snowfall.

\subsection{Trend of snowfall}

The mean annual snowfall varied from $0.305 \mathrm{~mm}$ in 1999 to 1.723 in 1994. The temporal linear trend analysis of snowfall in Satluj basin from 1976 to 2008 is shown in figure 5 . The significance and magnitude of trends is given in table 3 . The linear trend analysis of the mean annual values of snowfall showed slightly decreasing trend. The significance test carried out using Mann-Kendall method showed that the decreasing trend is insignificant at 95\% confidence level. The pre-monsoon and postmonsoon periods also showed insignificant negative trends for the same time period. However, for 

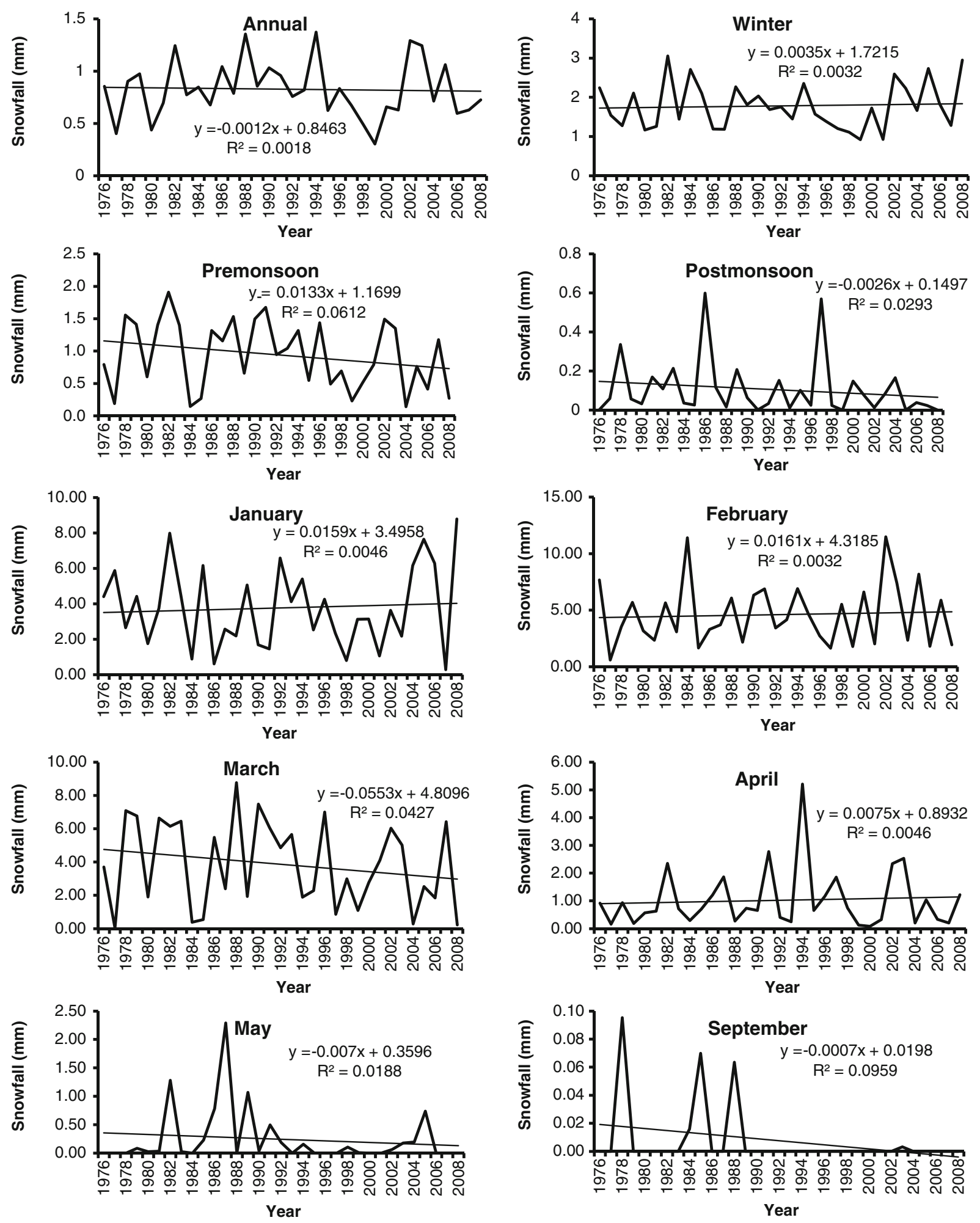

Figure 5. Annual, seasonal, monthly and elevation-wise, linear trend analysis of average values of snowfall from $1976-2008$. (Note: There are no values of snowfall for June, July and September.)

the winter period the trend was positive, being insignificant statistically at $95 \%$ confidence level. The monsoon period did not exhibit any trend because the precipitation during this period occurs mainly in the form of rainfall. Month-wise, the trend analysis showed insignificant positive trend for January, February, and April whereas, in case of March, May, September, October, November, and December insignificant negative trends were observed. The positive trend for the months of January, February, and April is also reflected by the positive trend for the winter season. 

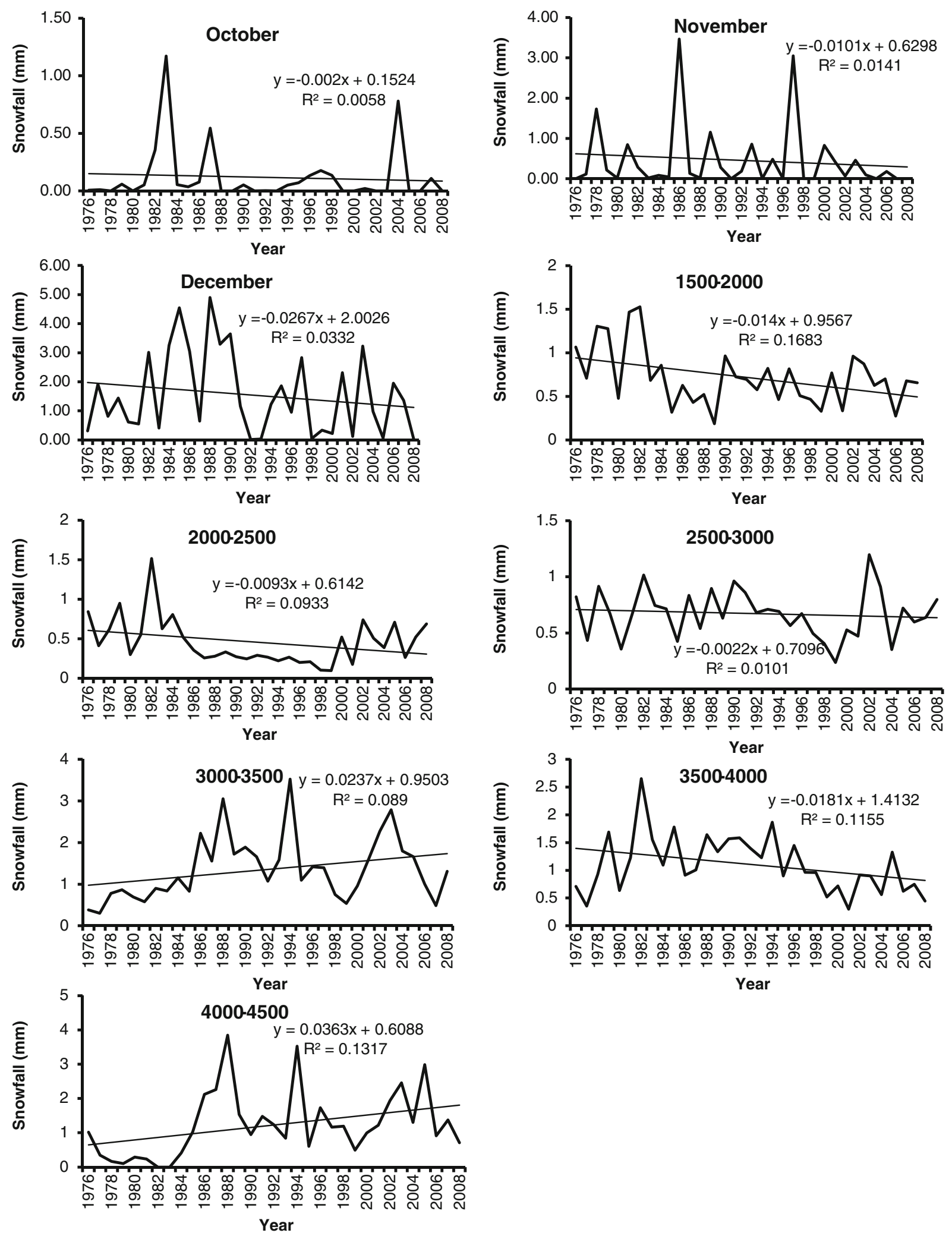

Figure 5. (Continued.)

\subsection{Trend of temperature}

The temporal linear trend analysis of temperature is shown in figure 6 . The significance and magnitude of trends is given in table 3. During the period 1984-2008, the mean annual air temperature was about $16^{\circ}$ to $22^{\circ} \mathrm{C}$ in case of $T_{\max }$ whereas the $T_{\min }$ varied from $7^{\circ}$ to $8^{\circ} \mathrm{C}$. The trend analysis of the temperature showed increasing trends for the $T_{\max }$ and $T_{\min }$. The positive trends in $T_{\min }$ 
Table 3. Annual, seasonal, monthly and elevation-wise, trend analysis based on Mann-Kandell and Sens slope of average values of snowfall (1976-2008) and temperature, i.e., $T_{\max }$ and $T_{\min }$ (1984-2008).

\begin{tabular}{|c|c|c|c|c|c|c|c|c|c|c|}
\hline \multirow[b]{2}{*}{ Sl. no. } & \multirow[b]{2}{*}{$\begin{array}{l}\text { Time period/ } \\
\text { elevation zone }\end{array}$} & \multicolumn{3}{|c|}{ Snowfall } & \multicolumn{3}{|c|}{$T_{\max }$} & \multicolumn{3}{|c|}{$T_{\min }$} \\
\hline & & $\begin{array}{l}\text { Sens } \\
\text { slope }\end{array}$ & $\begin{array}{c}\mathrm{Z} \\
\text { statistics }\end{array}$ & $\begin{array}{c}\text { Nature of } \\
\text { trend }\end{array}$ & $\begin{array}{l}\text { Sens } \\
\text { slope }\end{array}$ & $\begin{array}{c}\mathrm{Z} \\
\text { statistics }\end{array}$ & $\begin{array}{c}\text { Nature of } \\
\text { trend }\end{array}$ & $\begin{array}{l}\text { Sens } \\
\text { slope }\end{array}$ & $\begin{array}{c}\mathrm{Z} \\
\text { statistics }\end{array}$ & $\begin{array}{l}\text { Nature of } \\
\text { trend }\end{array}$ \\
\hline 1 & January & 0.0039 & 0.031 & Positive & 0.0429 & 0.6072 & Positive & 0.0626 & 1.3079 & Positive \\
\hline 2 & February & 0.0119 & 0.2479 & positive & -0.037 & -0.2803 & Negative & 0.0667 & 1.775 & Positive \\
\hline 3 & March & -0.0653 & -1.3635 & Negative & 0.0658 & 1.0743 & Positive & 0.0464 & 1.448 & Positive \\
\hline 4 & April & 0.0013 & 0.1859 & Positive & 0.0896 & 1.2612 & Positive & 0.0663 & 1.6348 & Positive \\
\hline 5 & May & 0 & -0.4183 & Negative & 0.0161 & 0.3737 & Positive & 0.0182 & 0.5138 & Positive \\
\hline 6 & June & - & - & - & -0.0329 & -0.9342 & Negative & 0.0214 & 1.0743 & Positive \\
\hline 7 & July & - & - & - & -0.0013 & -0.0467 & Negative & 0.022 & 1.0743 & Positive \\
\hline 8 & August & - & - & - & -0.0159 & -0.4671 & Negative & -0.007 & -0.2803 & Negative \\
\hline 9 & September & 0 & -0.7747 & Negative & -0.0065 & -0.1401 & Negative & 0.0141 & 0.327 & Positive \\
\hline 10 & October & 0 & -0.7437 & Negative & 0.0006 & 0.100 & Positive & 0.0291 & 1.0276 & Positive \\
\hline 11 & November & -0.0014 & -1.2705 & Negative & 0.0284 & 0.7006 & Positive & 0.0512 & 2.4289 & Positive \\
\hline 12 & December & -0.0201 & -1.0226 & Negative & 0.012 & 0.1401 & Positive & 0.0167 & 0.6072 & Positive \\
\hline 13 & Winter Season & 0.0004 & 0.031 & Positive & 0.0186 & 0.4204 & Positive & 0.0497 & 1.9618 & Positive \\
\hline 14 & Pre-monsoon & -0.0141 & -1.5804 & Negative & 0.0542 & 0.9342 & Positive & 0.051 & 1.6348 & Positive \\
\hline 15 & Monsoon & & & & -0.0118 & -0.4671 & Negative & 0.0089 & 0.7941 & Positive \\
\hline 16 & Post-monsoon & -0.0016 & -1.6579 & Negative & 0.025 & 0.5138 & Positive & 0.0287 & 1.2145 & Positive \\
\hline 17 & Annual & -0.0016 & -0.2789 & Negative & 0.0216 & 0.5605 & Positive & 0.0382 & 2.2421 & Positive \\
\hline 18 & $<1500$ & - & - & - & -0.0365 & -1.3546 & Negative & 0.0041 & 0.327 & Positive \\
\hline 19 & $1500-2000$ & -0.1233 & -1.0513 & Negative & - & - & - & - & - & - \\
\hline 20 & $2000-2500$ & -0.0467 & -0.4506 & Negative & - & - & - & - & - & - \\
\hline 21 & $2500-3000$ & -0.05 & -0.1502 & Negative & 0.0738 & 2.7559 & Positive & 0.0598 & 2.8493 & Positive \\
\hline 22 & $3000-3500$ & 0.0225 & 0.7509 & Positive & 0.0506 & 1.6582 & Positive & 0.0725 & 3.3398 & Positive \\
\hline 23 & $3500-4000$ & -0.09 & -0.4506 & Negative & 0.0971 & 1.1677 & Positive & 0.1179 & 2.1487 & Positive \\
\hline 24 & $>4000$ & 0.145 & 0.4506 & Positive & - & - & - & - & - & - \\
\hline
\end{tabular}

Note: Bold values reflect significant trend at $95 \%$ confidence level.

were found to be significant at 95\% confidence level. Shrestha et al. (1999) in the central/eastern Himalayas have reported positive trends of temperature $\left(0.06-0.12^{\circ} \mathrm{C} / \mathrm{yr}\right)$. The seasonal trend analysis of temperature showed that in case of $T_{\max }$, the trend was positive except for the monsoon season during which an insignificant negative trend was observed. During winter season, the mean $T_{\max }$ has also rose significantly by $3.28^{\circ} \mathrm{C}$ in the northwestern Himalaya during the past two decades (Bhutiyani et al. 2007). Bhutiyani et al. (2009) deduced a significant warming of $1.6^{\circ} \mathrm{C}$ in northwest Himalayas in the last century (1901-2000), with winters warming at a faster rate. However, the $T_{\min }$ showed positive trends for all the seasons. During winter period, the positive trend in $T_{\min }$ was found to be significant at $95 \%$ confidence level. Dash et al. (2007) found a negative trend $\left(1.98^{\circ} \mathrm{C}\right)$ in $T_{\min }$ over the western Himalaya during 19551972, followed by a positive trend in recent years. In case of temperature, the $T_{\max }$ showed insignificant negative trend for the month of Febuary followed by negative trends from June to September whereas the $T_{\max }$ showed insignificant trend for the month of August only. For rest of the months, both $T_{\max }$ and $T_{\min }$ showed positive trends. For the month of November, the $T_{\max }$ showed positive trend which was significant at $95 \%$ confidence level. The mean annual temperature has exhibited increasing trends from 1901 to 1982 over India (Hingane et al. 1985).

\subsection{Temporal trend of snowfall and temperature with altitude}

In order to understand the nature of trends with respect to elevation, the Satluj basin was divided into 10 elevation zones. The linear trend is shown in figures 5 and 6 . The nature and significance of the climatic variables is shown in table 3 . In figure 7 , the nature and significance of trend of average values of data is represented with respect to elevation, in which the $\mathrm{x}$-axis shows the elevation whereas the $y$-axis indicates nature of trend (Z statistics of measured variable) for each elevation zone. The trends are demarcated with plus and minus signs with the bold sign illustrating the significance. The trend analysis of snowfall in elevation zones of 15002000, 2000-2500 and 2500-3000 $\mathrm{m}$ amsl showed 

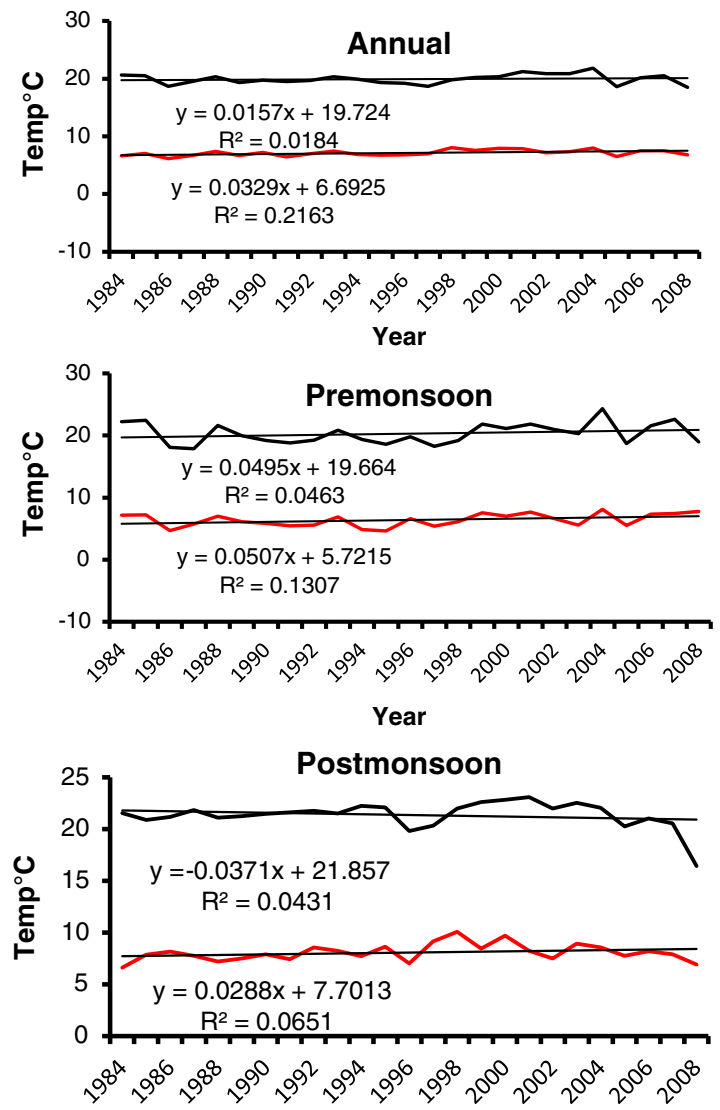

Year
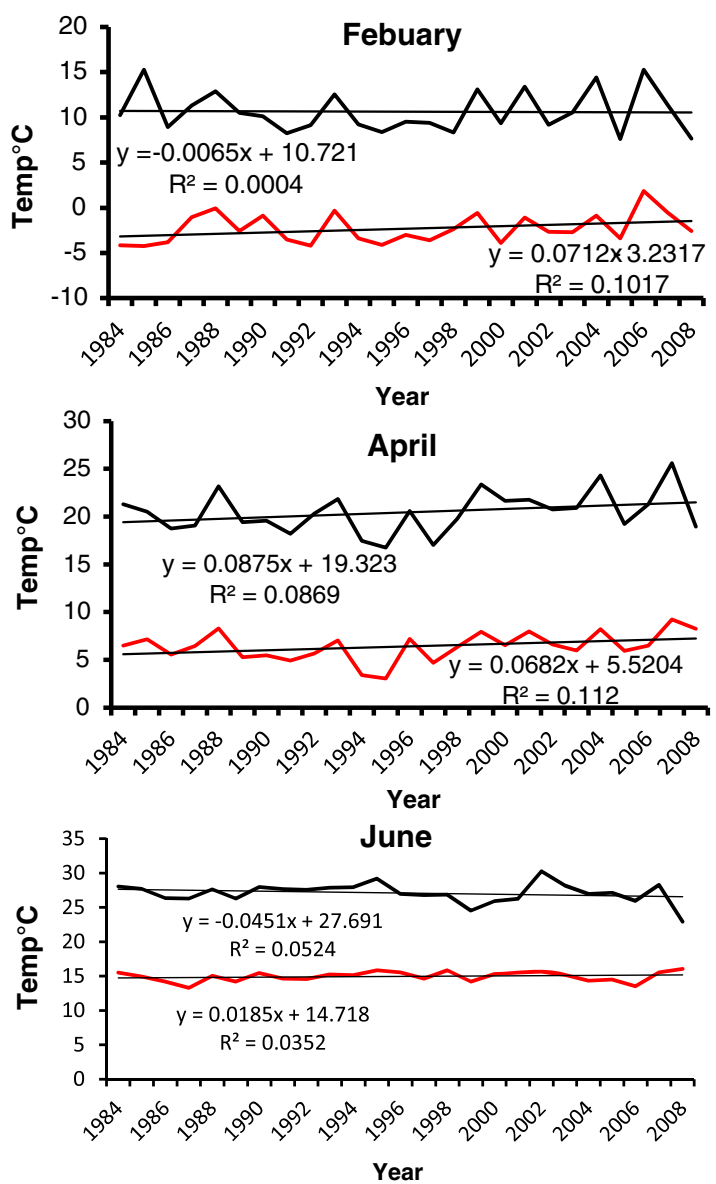
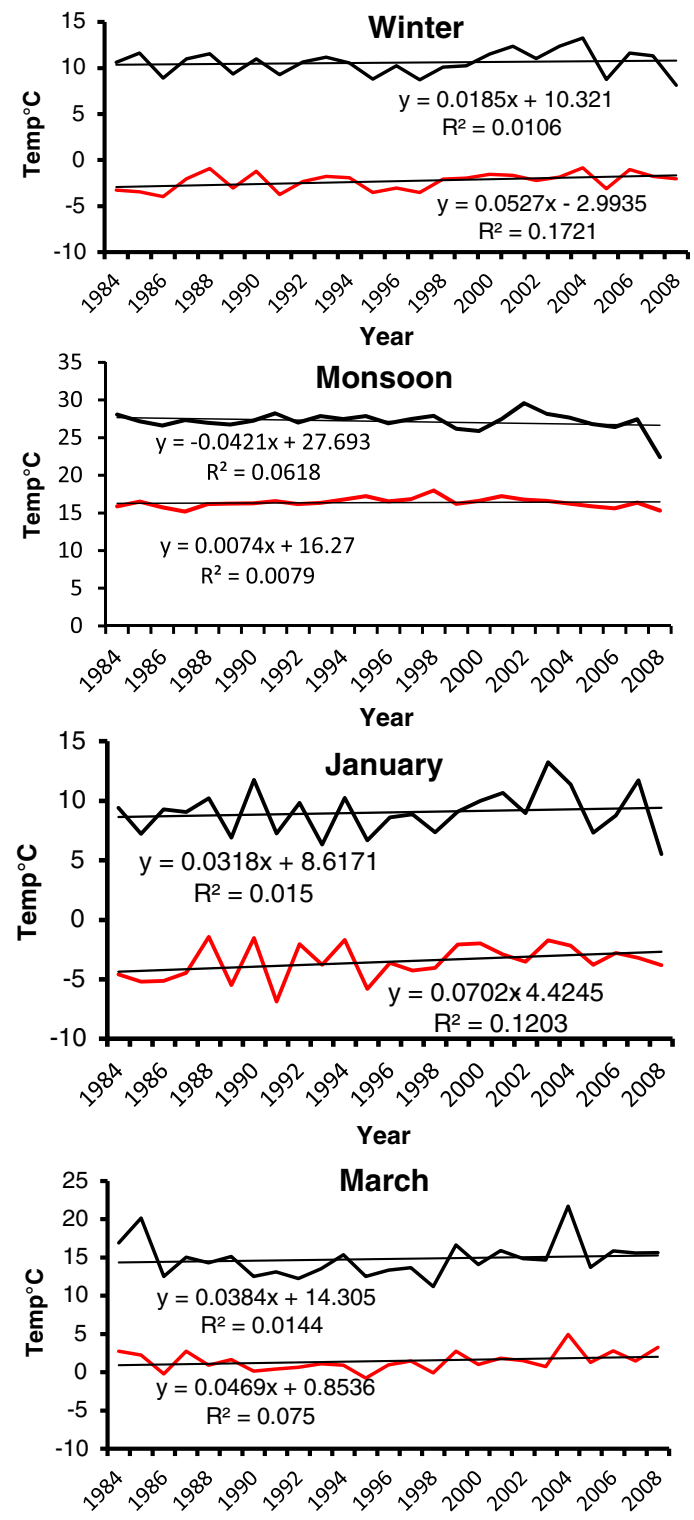

Year
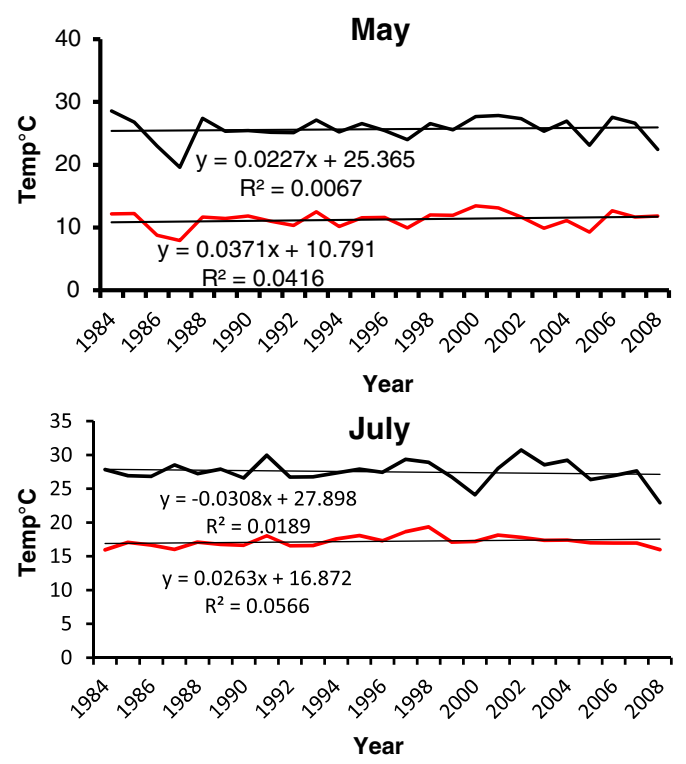

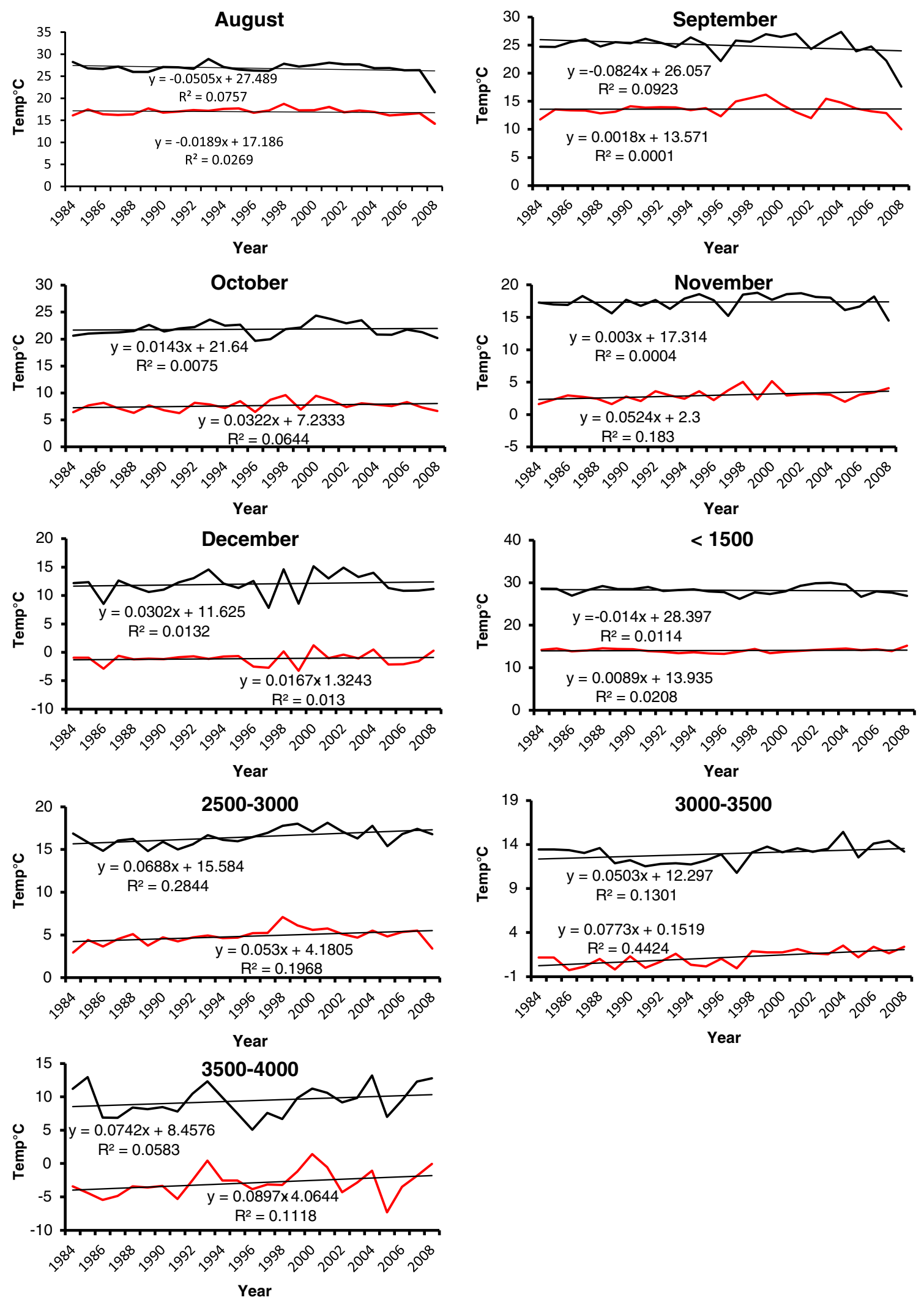

Figure 6. Annual, seasonal, monthly and elevation-wise, linear trend analysis of average values of temperature from 19842008. (Note: Dark coloured line shows trend in $T_{\max }$ and red coloured line shows trend in $T_{\min }$.)

negative trends which was statistically insignificant at $95 \%$ confidence level. The insignificant negative trend was also observed for the elevation zone of 3500-4000 m amsl. However, in elevation zones, i.e., $3000-3500$ and $4000-4500 \mathrm{~m}$ amsl, the trend was positive which was insignificant at $95 \%$ 
confidence level. It is to be noted that the snowfall pattern up to an elevation zone between 3500 and $4000 \mathrm{~m}$ amsl is likely to be most sensitive to climate change.

The temperature showed significantly positive trends for all the elevation zones. However, for an elevation zone of $<1500 \mathrm{~m}$ amsl, the $T_{\max }$ showed insignificant positive trend. The $T_{\max }$ showed significant trend for an elevation zone of $2500-3000 \mathrm{~m}$ amsl whereas, the $T_{\min }$ showed significant trend for the elevation zones of 2500 $3000,3000-3500$ and 3500-4000 $\mathrm{m}$ amsl at $95 \%$ confidence level.

\section{Discussion}

The snow forms a vital freshwater resource in the spring and summer season as the snow melts. However, the warming makes a shorter snow season with more precipitation falling as rain rather than snow and therefore, it becomes essential to understand snowfall patterns in response to changing climate. Overall, the trend analysis of mean snowfall annually, seasonally, monthly and elevation-wise from 1976 to 2008 showed negative trends. During the winter season, January, February, and April positive trends were observed. The trends were negative for the elevation zones of 1500-2000, 2000-2500, 2500-3000, and 3500-4000 $\mathrm{m}$ amsl except 3000-3500 $\mathrm{m}$ amsl and above $>4000 \mathrm{~m}$ amsl. However, the trends were found to be statistically insignificant at 95\% confidence level. The lack of significant trends could be caused by the mixing of the data of all stations (21 stations in the present study), independent of elevation and local climatic differences. During the period from 1984 to 2008 , the temperature $\left(T_{\max }\right.$ and $\left.T_{\min }\right)$ also showed positive trends. In case of $T_{\max }$, positive trends were observed for January, March to May, and October to December, pre-monsoon, post-monsoon and winter seasons. However, in case of $T_{\min }$, all the months (except July) and seasons exhibited positive trends. The $T_{\min }$ positive trends were found to be significant for November, annual, and winter season. All over India, Arora et al. (2005) have reported an increase of $0.94^{\circ} \mathrm{C} / 100$ yrs in temperature for the post-monsoon season and $1.1^{\circ} \mathrm{C} / 100$ yrs for the winter season. It is further substantiated by an increase in mean annual temperatures of $0.57^{\circ} \mathrm{C} / 100$ yrs (Pant and Rupa 1997). However, Sinha et al. (1997) showed that the rise in the $T_{\min }$ is caused by rapid urbanization, which is then partly responsible for the changes in mean annual temperatures. Elevation-wise, the $T_{\max }$ showed positive trends for the elevation zones of 2500-3000, 3000-3500, 3500-4000 $\mathrm{m}$ amsl except an elevation zone of
$<1500 \mathrm{~m}$ amsl. For the elevation zone of $2500-$ $3000 \mathrm{~m}$ amsl, the trend was statistically significant at $95 \%$ confidence level. However, the $T_{\min }$ positive trends were found to be significant above an elevation zone of $2500 \mathrm{~m}$ amsl at $95 \%$ confidence level. An increase of 1.0 and $3.4^{\circ} \mathrm{C}$ in $T_{\max }$ and $T_{\min }$ across the Himalayan region during the period from 1988 to 2008 was reported by Shekhar et al. (2010). In general, the global mean surface temperature has increased on average by $0.8^{\circ} \mathrm{C}$ in the last century and by $0.6^{\circ} \mathrm{C}$ in the past three decades from 1975 to 2005 (Hansen et al. 2006). Thus, the positive increasing trends of $T_{\max }$ and particularly $T_{\min }$, annually, seasonally, as well as elevation-wise is likely to be a dominant factor to cause a decline in snowfall in the present basin. The increase in temperature (shift from solid to liquid precipitation) is one of the important factors responsible for reduction in snowfall (Thayyen et al. 2005; Dimri and Mohanty 2007). Furthermore, the second World Climate Conference held in Geneva in 1990 comprehensively treated the problem of climate change due to greenhouse effect (Jager and Ferguson 1991). It was suggested that the gradual increase in the air temperature for next decades (Schneider 1990) will decline the number of days with snowfall (Bayr et al. 1994; Bohm 1986; Schoner et al. 2000). The decline in snowfall along with the rise in temperature in the present basin are qualitatively consistent with the observed trends in precipitation and temperature at nearby stations or at other regions. Dimri and Dash (2010, 2012) and Shekhar et al. (2010) have reported the decreasing trends in precipitation associated with a reduction in total seasonal snowfall with increase in temperature in the Himalayas. In the Tirungkhad basin which is a sub-basin of Satluj basin, a decrease in snowfall (SWE) with increase in temperature $\left(T_{\max }\right.$ and $\left.T_{\min }\right)$ has been reported (Mir et al. 2014). Additionally, in the northwestern Himalaya, a significant decreasing trend has been reported in the monsoon precipitation from 1866 to 2006 (Bhutiyani et al. 2009). In North America, snow cover has decreased in the winter months (Frei et al. 1999; Selkowitz et al. 2002; Mote et al. 2005) with most pronounced decrease in the spring months due to rise in temperature (McCabe and Legates 1995; Hughes and Robinson 1996). Houghton et al. (1996) noted a $10 \%$ decrease in snow cover area over the northern hemisphere between 1973 and 1994 driven primarily by rising temperatures, although the mechanism for change operates particularly through regional, rather than global or hemispheric, atmospheric systems (McCabe and Legates 1995; Clark et al. 1999; Ye 2000).

In the present study, it was observed that the positive trends of snowfall prevailed in January, 


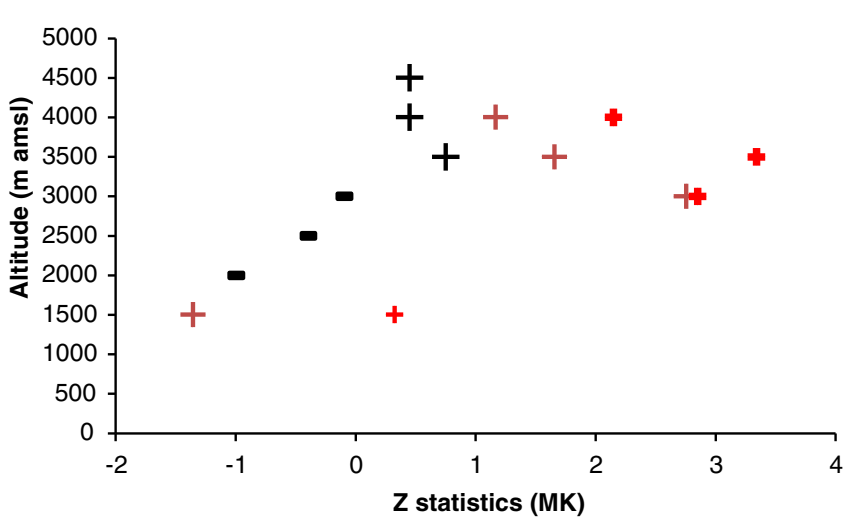

Figure 7. Nature and significance of trend of average values of data with respect to elevation. The black coloured signs denote trends in snowfall whereas the dark red coloured signs reflect the trends in $T_{\max }$ and light red coloured signs show $T_{\min }$ trends. The significant trends are shown in bold sign.

February, and winter seasons reflect that although the temperature is increasing, it is still below the freezing in the coldest months, especially at the higher elevation areas. The positive trend in snowfall during winter season may also be attributed to the increased precipitation as snowfall and increased temperature (particularly $T_{\min }$ in the present study). The increased temperature in cold inland areas is less sensitive and is likely to result in more precipitation as snow, due to the enhanced capacity of air to contain more moisture (Howat and Tulaczyk 2005; Mote 2006; Adam et al. 2009; Stewart 2009; Rasmussen et al. 2011). However, the existence of negative trends in snowfall during the other seasons may be because of precipitation falling mainly as rain induced by the warming of climate. The snowfall exhibited negative trends in lower elevation zone (i.e., below $3000 \mathrm{~m} \mathrm{amsl}$ ) and positive trends at higher elevation zone (i.e., 30003500 and $4000-4500 \mathrm{~m}$ amsl). The snow reductions are most pronounced at temperatures near freezing, i.e., those that tend to occur more often at lower elevations (Knowles et al. 2006; IPCC 2007), whereas at higher altitudes, increasing precipitation is likely to cause an increase in snowfall (Howat and Tulaczyk 2005; Mote 2003, 2006). The significant positive trends in $T_{\min }$ at higher elevation zones (i.e., above $2500 \mathrm{~m}$ amsl) are likely to cause an increase in snowfall, although the $T_{\max }$ showed insignificant positive trend below an elevation zone of $1500 \mathrm{~m}$. For example in Europe, despite the increasing temperatures, there have been very few changes in snow cover because of increasing precipitation at the highest elevation. However, there have been winters with very little snow at lowest altitudes (Beniston 1997). Thus, the declines in snowfall were found to be altitude dependent (Beniston 1997; Hantel et al. 2000).

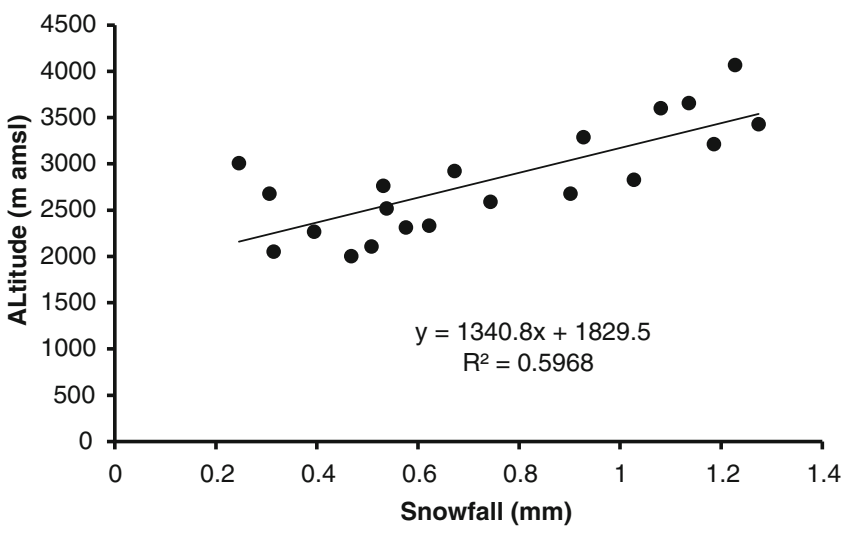

Figure 8. Relationship between average values of snowfall based on 21 stations and their respective elevation in the Satluj basin.

Consequently, changes in water cycling and availability will be particularly obvious at low elevations that will be the first to be affected by the effects of rising temperatures on declining snow (Mote et al. 2005; Knowles et al. 2006; IPCC 2007; Rasmussen et al. 2011). Even though the number of stations and their distribution with altitude is limited, a pattern in the plots was found. This can be interpreted as a result of climate variability. The snowfall was obtained from 21 stations falling in the basin at different elevations zones, therefore, the effect of elevations on the snowfall was investigated as shown in figure 8. A significantly moderate correlation $\left(R^{2}=0.59\right)$ was observed between the snowfall and the elevation, which revealed that with increase in elevation the snowfall increases. The effect of the aspect or orientation may be the possible reason for the moderate correlation between altitude and snowfall. Thus, it was observed that the temperature $\left(T_{\max }\right.$ and $\left.T_{\min }\right)$ and precipitation are the main factors affecting snowfall characteristics through accumulation and melting processes.

\section{Conclusion}

The trend analysis of the variability of snowfall from 1976 to 2008 for a period of 33 years and temperature $\left(T_{\max }\right.$ and $\left.T_{\min }\right)$ from 1984 to 2008 for a period of 24 years has reflected some important results. On comparison, a highly positive correlation of $0.95 \%$ was found between MODIS SCA and ground based snowfall from 2000 to 2009 for seven elevation zones, which substantiate the reliability of the snowfall data for change detection studies. There are no indications of significant trends in the mean values of snowfall for annual, seasonal and, monthly periods as well as for the average values of annual snowfall over seven elevation zones in the Satluj basin. However, if this decreasing trend of snowfall in the basin continues, it may result 
in significant changes in future with direct consequences on the river flows and water resources in the region, besides having an effect on seasonal melt water pulse, agriculture dependent on irrigation, and water supply for the populated downstream areas. The decreasing trends in snowfall can be explained by the increasing trends in temperature particularly $T_{\min }$. The $T_{\max }$ showed dominantly positive trends which were insignificant at 95\% confidence level. However, the $T_{\min }$ showed positive trends with the exception of August during which insignificant negative trend was present. The $T_{\min }$ showed significant trends for the month of November, winter season, as well as for the elevation zones of 2500-3000, 3000-3500, and $3500-4000 \mathrm{~m}$ amsl. Thus, the $T_{\min }$ may be the dominant factor responsible for the decline in snowfall in the study area. In addition, the negative trends of snowfall around lower elevation zones $(<3000 \mathrm{~m}$ amsl $)$ clearly confirm the role of temperature in reducing snowfall from 1976 to 2008. This increased temperature as a result of climate change will lead to a continued decrease in snow accumulation and will result in earlier snowmelt and less water storage in the area. Therefore, these results have significant implications for water resources managers in the area. For example, the Bhakra dam constructed on Satluj River is the major point of water supply and electricity generation in this basin. Since snowmelt provides much of the water used during summer for irrigation, municipal and industrial water supply, and other uses in the basin, future changes in snowfall and hence, snow cover are of great concern. In general, the understanding of snowfall patterns in response to temperature will provide the comprehension for better management of water-related activities in the basin. Furthermore, the declines of snowfall in response to increase in temperature $\left(T_{\max }\right.$ and $\left.T_{\min }\right)$ may provide a further proof of global warming.

\section{Acknowledgements}

First, thanks are due to BBMB for providing meteorological data and UGC for providing the fellowship. The authors would like to thank NASA for making the MODIS datasets freely available under the umbrella USGS web server. Special thanks to the reviewers for their significant comments for improving the quality of the paper. Thanks to Ms Neha Jain, SRF (NIH, Roorkee) for her help.

\section{References}

Adam J C, Hamlet A F and Lettenmaier D P 2009 Implications of global climate change for snowmelt hydrology in the 21st century; Hydrol. Process. 23 962-972.
Anonymous 1988 Snow Hydrology Studies in Sutlej and Beas Catchments In: Proceedings of the Workshop on Snow Hydrology, Manali, India.

Armstrong R L and Brun E 2008 Snow and Climate: Physical Processes, Surface Energy Exchange and Modelling; Cambridge University Press, 256p.

Arora M, Goel N K and Singh R 2005 Evaluation of temperature trends over India; Hydrol. Sci. J. 50(1) 8193.

Aziz O I A and Burn D H 2006 Trends and variability in the hydrological regime of the Mackenzie River Basin; J. Hydrol. 319 282-294.

Barnett T P, Dumenil L and Latif M 1989 The effect of Eurasian snow cover on regional and global climate variations; J. Atmos. Sci. 46(5) 661-685.

Barry R G 1985 The Cryosphere and Climate Change: Detecting the Climate Effects of Increasing $\mathrm{CO}_{2}$; US Department of Energy, pp. 109-141.

Bayr K J, Hall D K and Kovalick W M 1994 Observation on glaciers in the Eastern Austria Alps using satellite data; Int. J. Remote Sens. 15(9) 1733-1752.

BBMB 1988 Snow hydrology studies in India with particular reference to the Satluj and Beas catchments; In: Proc. Workshop on Snow Hydrology (Manali, India, 23-26 November, 1988).

Bednorz E 2004 Snow cover in eastern Europe in relation to temperature, precipitation and circulation; Int. J. Climatol. 24 591-601.

Beniston M 1997 Variations in snow depth and duration in the Swiss Alps over the last 50 years: Links to changes in the large scale climatic forcing; Clim. Change $\mathbf{3 6}$ 281-300.

Beniston M, Keller F and Koffi B 2003 Estimation of snow accumulation and volume in the Swiss Alps under changing climatic conditions; Theor. Appl. Climate $\mathbf{7 6}$ 125-140.

Bhutiyani M R, Kale V S and Pawar N J 2007 Longterm trends in maximum, minimum and mean annual air temperatures across the Northwestern Himalaya during the twentieth century; Clim. Change, doi: 10.1007/s10584-006-9196-1.

Bhutiyani M R, Kale V S and Pawar N J 2009 Climate change and the precipitation variations in the northwestern Himalaya: 1866-2006; Int. J. Climatol. 30(4) 535-548.

Bohm R 1986 Der Sonnblick Vienna: Oesterreichischer Bundesverlag, 222p.

Brown R D 1998 Spatial and temporal variability of Canadian monthly snow depths 1946-1995; Atmosphere-Ocean 36 37-54.

Brown R D and Goodison B E 1996 Interannual variability in reconstructed Canadian snow cover, 1915-1992; J. Climate 9 1299-1318.

Brown R, Walker A and Goodison B 2000 Seasonal snow cover monitoring in Canada; An assessment of Canadian contributions for global climate monitoring, $57^{\text {th }}$ Eastern Snow Conference Syracuse, New York.

Cannarozzo M, Noto L V and Viola F 2006 Spatial distribution of rainfall trends in Sicily (1921-2000); Phys. Chem. Earth 31 1201-1211.

Chang A T C, Foster J L and Hall D K 1990 Satellite sensor estimates of northern hemisphere snow volume; Int. J. Remote Sens. 11 167-171.

Clark M P, Serreze M C and Robinson D A 1999 Atmospheric controls on Eurasian snow extent; Int. J. Climatol. 19 27-40.

Dash S K, Jenamani R K, Kalsi S R and Panda S K 2007 Some evidence of climate change in twentieth-century India; Clim. Change 85 299-321. 
Deems J S, Fassnacht S R and Elder K J 2006 Fractal distribution of snow depth from LiDAR data; J. Hydrometeorol. 7 285-297.

Derksen C, Wulder M, Ledrew E and Goodison B 1998 Associations between spatially auto correlated patterns of SSM/I-derived prairie snow cover and atmospheric circulation; Hydrol. Process 12 2307-2316.

Dickson R R 1984 Eurasian snow cover versus Indian monsoon rainfall - an extension of the Hahn-Shukla results; J. Clim. Appl. Meteorol. 23 171-173.

Dimri A P and Dash S K 2010 Winter Temperature and Precipitation changes in the Siachen Glacier; Curr. Sci. 98(12) 1620-1625.

Dimri A P and Dash S K 2012 Wintertime climatic trends in the western himalayas; Clim. Change 111(3-4) 775-800.

Dimri A P and Mohanty U C 2007 Location specific prediction of maximum and minimum temperature over the Western Himalayas; Meteorol. Appl. 14 79-93.

Dozier J 1989 Spectral signature of alpine snow cover from the Landsat Thematic Mapper; Remote Sens. Environ. 28 9-22.

Frei A, Robinson D A and Hughes M G 1999 North American snow extent 1900-1994; Int. J. Climatol. 19 1517-1534.

Goodison B E and Walker A E 1993 Use of snow cover derived from satellite passive microwave data as an indicator of climate change; Ann. Glaciol. 17 137-142.

Groisman P Y, Karl T R and Knight R W 1994 Observed impact of snow cover on the heat balance and the rise of continent spring temperature; Science 263(14) 198-200.

Hall D K, Riggs G A and Salomonson V V 1995 Development of methods for mapping global snow covers using Moderate Resolution Imaging Spectroradiometer (MODIS) data; Remote Sens. Environ. 54(2) 127-140.

Hall D K, Riggs G A, Salomonson V V, DiGirolamo N E and Bayr K J 2002 MODIS snowcover products; Remote. Sens. Environ. 83 181-194.

Hall D K, Riggs G A and Salomonson V V 2007 (updated weekly) MODIS/Terra Snow Cover 8-Day L3 Gobal 500 $\mathrm{m}$ Grid V005. National Snow and Ice Data Centre; Digital media, Boulder.

Hansen J, Sato M, Ruedy R, Lo K and Lea D W 2006 Global temperature change; Proc. Natl. Acad. Sci. USA 103 14288-14293.

Hantel M, Ehrendorfer M and Haslinger A 2000 Climate sensitivity of snow cover duration in Austria; Int. J. Climatol. 20 615-640.

Hasnain S I 2008 Impact of climate change on Himalayan glaciers and glacier lakes; Proc. Taal 2007, The 12th Lake Conference; pp. 1088-1091.

Helsel D R and Hirsch R M 1992 Statistical Methods in Water Resources (Amsterdam: Elsevier), 522p.

Hingane L S, Rup K K and Ramanamurthy B V 1985 Long term needs of surface air temperature in India; Int. J. Climatol. 5 521-528.

Houghton J F, Filho L G M, Callander B A, Harris N, Kattenberg A and Maskell K 1996 Climate Change 1995: The Science of Climate Change (Cambridge: Cambridge University Press).

Howat I M and Tulaczyk S 2005 Trends in spring snowpack over a half-century of climate warming in California, USA; Ann. Glaciol. 40 151-156.

Hughes M G and Robinson D A 1996 Historical snow cover variability in the Great Plains region of the USA: 1990 through to 1993; Int. J. Climatol. 16 10051018.

IPCC 2001 The Scientific Basis. Contribution of Working Group I to the Third Assessment Report of the Intergovernmental Panel on Climate Change (eds) Houghton J
T et al., Cambridge University Press, Cambridge, USA, 881p.

IPCC 2007 Climate change 2007: The physical science basis; Agenda 6(07).

Jaagus J 2006 Climatic changes in Estonia during the second half of the 20th century in relationship with changes in large-scale atmospheric circulation; Theor. Appl. Climatol. 83 77-88.

Jager J and Ferguson H L 1991 Climate change: Science, impacts and policy; Proceedings of the second World Climate Conference, Geneva, Switzerland, Cambridge: Cambridge University Press.

Jain S K, Kumar N and Ahmed T 1998 SLURP model and GIS for estimation of runoff in a part of Satluj catchment, India; Hydrol. Sci. J. 43(6) 875-884.

Jain S K, Ajanata G and Saraf A K 2008 Accuracy assessment of MODIS, NOAA and IRS data in snow cover mapping under Himalayan condition; Int. J. Remote Sens. 29(20) 5863-5878.

Jain S K, Goswami A and Saraf A K 2010 Assessment of snowmelt runoff using remote sensing and effect of climate change on runoff; Water Res. Mgt. 24 17631777.

Jensen J R 1996 Introductory digital image processing: A remote sensing perspective, 2 nd edn, Prentice-Hall Inc.

Kazuyuki S 2003 The potential role of snow cover in forcing interannual variability of the major Northern Hemisphere mode; Geophys. Res. Lett. 30 35-38.

Ke C Q, Yu T, Yu K, Tang G D and King L 2009 Snowfall trends and variability in Qinghai, China; Theor. Appl. Climatol. 98 251-258, doi: 10.1007/s00704-009-0105-1.

Keller F, Kinast F and Beniston M 2000 Evidence of the response of vegetation to environmental change at high elevation sites in the Swiss Alps; Regional Env. Change 1(2) $70-77$.

Kendall M G 1975 Rank correlation methods; 3rd edn, Hafner Publishing Company, New York, 128p.

Knowles N, Dettinger M D and Cayan D R 2006 Trends in snowfall versus rainfall in the Western United States; J. Climate 19 4545-4559.

Kripalani R H and Kulkarni A 1999 Climatology and variability of historical Soviet snow depth data: Some new perspectives in snow-Indian monsoon tele-connections; Clim. Dyn. 15 475-489.

Kulkarni A V, Mathur P, Rathore B P, Alex S, Thakur N and Kumar Manoj 2002 Effect of global warming on snow ablation pattern in the Himalayas; Curr. Sci. 83 120-123.

Laternser M and Schneebeli M 2003 Long-term snow climate trends of the Swiss Alps (1931-99); Int. J. Climatol. 23 $733-750$.

Lillesand T M, Kiefer R W and Chipman J W 2004 Remote sensing and image interpretation, 5th edn, (Lucknow: John Wiley \& Sons Ltd.).

Mann H B 1945 Non-parametric tests against trend; Econometrica 13 245-259.

McCabe G J and Legates D R 1995 Relationships between $700 \mathrm{hPa}$ height anomalies and $1^{\text {st }}$ April snowpack accumulation; Int. J. Climatol. 15 517-530.

Meissner S and Reller A 2005 Sustainable management of Alpine water potentials. Revue De Geographie Alpine; J. Alp. Res. 93(3) 5-29.

Mir R A, Jain S K, Saraf A K and Goswami A 2013 Detection of changes in glacier mass balance using satellite and meteorological data in Tirungkhad Basin located in Western Himalaya; J. Indian. Soc. Remote. Sens., doi: 10.1007/s12524-013-0303-2.

Mir R A, Jain S K, Saraf A K and Goswami A 2014 Glacier changes using satellite data and effect of climate 
in Tirungkhad basin located in western Himalaya; Geocart. Inter. (http://dx.doi.org/10.1080/10106049.2012. $760655)$.

Mote P W 2003 Trends in snow water equivalent in the Pacific northwest and their climatic causes; Geophys. Res. Lett. 30(12) 1601, doi: 10.1029/2003GL017258.

Mote P W 2006 Climate-driven variability and trends in mountain snowpack in western North America; J. Climate $196209-6220$.

Mote P W, Hamlet A F, Clark M P and Lettenmaier D P 2005 Declining mountain snowpack in western North America; Bull. Am. Meteorol. Soc. 86 39-49.

Pant G B and Rupa K 1997 Climate of South Asia; John Willey \& Sons, Chichester, UK, 320p.

Pimentel D, Berger B, Filibrto D, Newton M, Wolfe B, Karabinakis E, Cark S, Poon E, Abbett E and Nandagopal S 2004 Water resources: Agricultural and environmental issues; BioScience 54(10) 909-918.

Rasmussen R, Liu C and Ikeda K et al. 2011 High-resolution coupled climate runoff simulations of seasonal snowfall over Colorado: A process study of current and warmer climate; J. Climate 24 3000-3014.

Salomonson V V and Appel I 2006 Development of the Aqua MODIS NDSI fractional snow cover algorithm and validation results; IEEE Trans. Geosci. Remote Sens. 44(7) $1747-1756$.

Schadler B 2004 Climate change issues and adaptation strategies in a mountainous region: Case study Switzerland; In: OECD Global Forum on Sustainable Development: Development and Climate Change, env/epoc/ $\mathrm{gf} / \mathrm{sd} / \mathrm{rd}$ (2004)3/final, oecd, Paris, 9p.

Schneider S H 1990 Global warming: Are we entering the greenhouse century? 1st edn; Vintage Books, New York.

Schoner W, Auer I and Bohm R 2000 Climate variability and glacier reaction in the Austrian eastern Alps; Ann. Glaciol. 31 31-38.

Selkowitz D J, Fagre D B and Reardon B A 2002 Interannual variations in snowpack in the Crown of the Continent Ecosystem; Hydrol. Process 16 3651-3665.

Sen P K 1968 Estimates of the regression coefficient based on Kendall's tau; J. Am. Stat. Assoc. 63(324) 1379-1389.

Serreze M, Walsh J, Chapin F, Osterkamp T, Dyurgerov M, Romanosky V, Oechel W, Morison J, Zhang T and Barry R 2000 Observational evidence of recent change in the northern high-latitude environment; Clim. Change 46 159-207.

Sevruk B 1985 Conversion of snowfall depths to water equivalents in the Swiss Alps; Workshop on the Correction of Precipitation Measurements, 1-3 April, Zurich.
Shekhar M S, Chand H, Kumar S, Srinivasan K and Ganju A 2010 Climate-change studies in the western Himalaya; Ann. Glaciol. 51(54) 105-112.

Shrestha A B, Wake C P, Mayewski P A and Dibb J E 1999 Maximum temperature trends in the Himalaya and its vicinity: An analysis based on temperature records from Nepal for the period 1971-1994; J. Climate 12 27752787.

Sinha R K C, Mukhopadhya R K and Chowdhary S K 1997 Trend in maximum and minimum temperature and sea level pressure over India; Intromet 1997 IIT Delhi, Hauz Khas, New Delhi.

Singh P and Bengtsson L 2004 Hydrological sensitivity of a large Himalayan basin to climate change; Hydrol. Process. $182363-2385$.

Singh P and Kumar N 1997 Impact assessment of climate change on the hydrological response of a snow and glacier melt runoff dominated Himalayan River; J. Hydrol. 193 316-350.

Singh P and Jain S K 2002 Snow and glacier melt in the Satluj River at Bhakra dam in the western Himalayan region; Hydrol. Sci. 47(1) 93-106.

Singh P and Jain S K 2003 Modelling of stream flow and its components for a large Himalayan basin with predominant snowmelt yields; Hydrol. Sci. J. 48(2) 257-276.

Singh P and Quick M C 1993 Stream flow simulation of Satluj river in the Western Himalayas. Snow and Glacier Hydrology (Proceedings of the Kathmandu Symposium, November 2002); IAHS Publication No. 218, 261-271.

Stewart I T 2009 Changes in snowpack and snowmelt runoff for key mountain regions; Hydrol. Process. 23 78-94.

Thayyen R J and Gergan J T 2010 Role of glaciers in watershed hydrology: A preliminary study of a Himalayan Catchment; The Cryosphere 4 115-128.

Thayyen R J, Gergan J T and Dobhal D P 2005 Monsoonal control on glacier discharge and hydrographic characteristics, a case study of Dokriani glacier, Garhwal Himalaya, India; J. Hydrol. 36(1-4) 37-49.

Woodwell G M 2004 Mountains: Top down; Ambio, pp. 35-38.

Yang D, Kane D L, Hinzman L D, Zhang X, Zhang T and Ye H 2002 Siberian Lena river hydrologic regime and recent change; J. Geophys. Res. 107, doi: 10.1029/2002JD002542.

Ye H 2000 Decadal variability of Russian winter snow accumulation and its associations with Atlantic sea-surface temperature anomalies; Int. J. Climatol. 20 1709-1728.

Yue S and Hashino M 2003 Temperature trends in Japan: 1900-1996; Theor. Appl. Climatol. 75 15-27. 